\title{
Transforming growth factor- $\beta$ and endoglin signaling orchestrate wound healing
}

\author{
Manoj Valluru, Carolyn A. Staton, Malcolm W. R. Reed and Nicola J. Brown* \\ Department of Oncology, Microcirculation Research Group, Faculty of Medicine, Dentistry and Health, University of Sheffield, Sheffield, UK
}

\section{Edited by:}

Mariappan Muthuchamy, Texas A\&M

Health Science Center, USA

\section{Reviewed by:}

Zhe Sun, University of

MissouriColumbia, USA

Sanjukta Chakraborty, Texas A\&M

Health Science Center, USA

Gopal Jegadeesh Babu, University of

Medicine and Dentistry of New

Jersey, USA

\section{${ }^{*}$ Correspondence}

Nicola J. Brown, Department of

Oncology, Microcirculation Research

Group, Faculty of Medicine, Dentistry

and Health, University of Sheffield,

Beech Hill Road, Sheffield, South

Yorkshire 2RX, UK.

e-mail: n.j.brown@sheffield.ac.uk
Physiological wound healing is a complex process requiring the temporal and spatial coordination of various signaling networks, biomechanical forces, and biochemical signaling pathways in both hypoxic and non-hypoxic conditions. Although a plethora of factors are required for successful physiological tissue repair, transforming growth factor beta (TGF$\beta$ ) expression has been demonstrated throughout wound healing and shown to regulate many processes involved in tissue repair, including production of ECM, proteases, protease inhibitors, migration, chemotaxis, and proliferation of macrophages, fibroblasts of the granulation tissue, epithelial and capillary endothelial cells. TGF- $\beta$ mediates these effects by stimulating signaling pathways through a receptor complex which contains Endoglin. Endoglin is expressed in a broad spectrum of proliferating and stem cells with elevated expression during hypoxia, and regulates important cellular functions such as proliferation and adhesion via Smad signaling. This review focuses on how the TGF- $\beta$ family and Endoglin, regulate stem cell availability, and modulate cellular behavior within the wound microenvironment, includes current knowledge of the signaling pathways involved, and explores how this information may be applicable to inflammatory and/or angiogenic diseases such as fibrosis, rheumatoid arthritis and metastatic cancer.

\section{WOUND HEALING}

Wound healing is a complex process involving a number of interdependent stages including hemostasis, inflammation, proliferation, and remodeling (Gurtner et al., 2008). Different cell types, complex signaling events and numerous growth factors are involved in each phase of wound healing which are represented in Figure 1.

\section{HEMOSTASIS}

Upon tissue injury, the blood coagulation cascade is initiated, resulting in fibrin formation which provides a temporary scaffold for the influx of inflammatory cells. Platelets also aggregate at the site of injury, become activated by binding to the negatively charged extravascular tissue and degranulate, releasing different glycoproteins and growth factors such as platelet derived growth factor (PDGF), epidermal growth factor (EGF), transforming growth factor beta (TGF- $\beta$ ), vascular endothelial growth factor (VEGF), and basic fibroblast growth factor (bFGF) (Schultz, 2007; Kimmel et al., 2010).

The plethora of growth factors released during hemostasis regulate different events including the stimulation and recruitment of monocytes, neutrophil, and macrophages to the wound bed, thereby initiating the inflammatory phase. In addition endothelial vasculogenesis or angiogenesis is initiated, and fibroblasts are recruited to the site of injury for extracellular matrix production and remodeling (Quesada et al., 2007; Kimmel et al., 2010). The majority of cell types required for wound healing are recruited from a variety of niches including bone marrow, blood vessel, basal layer of epidermis, hair follicle bulge, and adipose tissue, which are enriched with stem or progenitor cells that differentiate into specific cell types in response to selective signaling molecules or growth factors during healing (Asahara et al., 1999; Hill et al., 2003; Urbich and Dimmeler, 2004; Clayton et al., 2007; Crisan et al., 2008; Ambler and Määttä, 2009; Blanpain and Fuchs, 2009).

\section{INFLAMMATORY PHASE}

Peripheral blood circulating hematopoietic stem cells (HSC) differentiate into white blood cells such as neutrophils and monocytes, which are recruited to the site of wound injury during the inflammatory phase. Monocytes subsequently differentiate into macrophages which secrete matrix metalloproteinases (MMPs) to remove debris at the wound site and promote the healing process (Dabiri and DiPersio, 2005). Neutrophils and macrophages also release different cytokines, chemokines, and growth factors including PDGF and TGF- $\beta$ which activate fibroblasts and initiate the proliferative phase (Gurtner et al., 2008; Kimmel et al., 2010).

\section{PROLIFERATIVE PHASE}

During the proliferative phase, fibroblasts infiltrate the wound, produce MMPs (Dabiri and DiPersio, 2005), new matrix, and interact with extracellular proteins through cell surface integrins thereby promoting granulation. Fibroblasts undergo a phenotypic change to myofibroblasts, which align along the border of the wound, generating a contractile force, facilitating wound closure. One study has demonstrated that neovascularization can be accomplished by a non-angiogenic process regulated by contraction, likely to be induced by proto- and myofibroblasts, with further angiogenesis optimizing blood vessel formation (Kilarski 


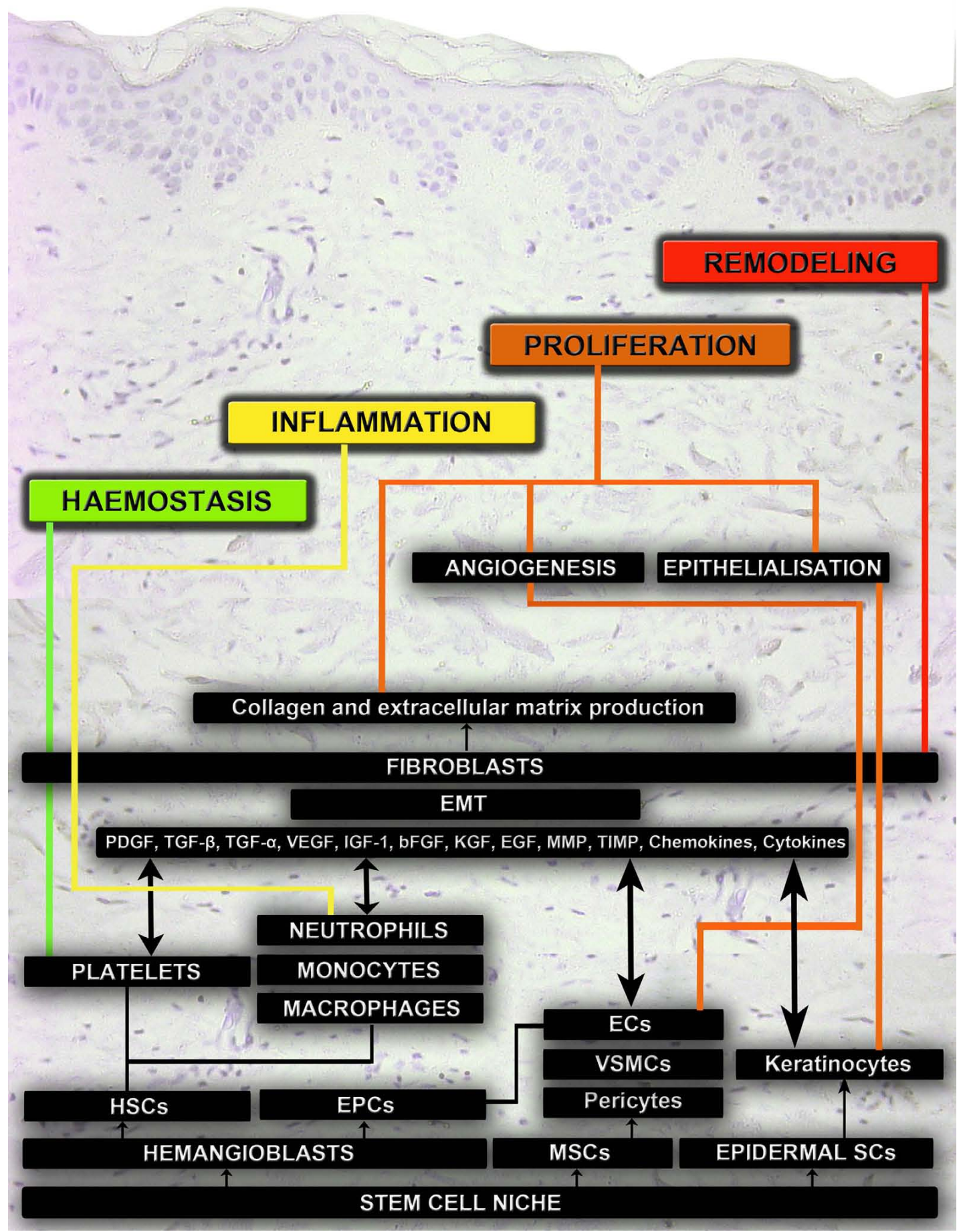

FIGURE 1 | Schematic representation of the cellular mechanisms that pattern acute wound healing. The four main phases of wound healing are hemostasis, inflammation, proliferation, and remodeling. Different cell types are involved in regulating biomechanical and biochemical functions during these phases of wound healing. The main source for these cell types are different stem cell niches. Hematopoietic stem cells (HSCs), platelets, neutrophils, and monocytes regulate hemostasis and inflammation.
Mesenchymal stem cells (MSCs), endothelial progenitor cells (EPCs), pericytes, vascular smooth muscle cells (VSMCs), endothelial cells (ECs), and fibroblasts regulate angiogenesis. Epithelial mesenchymal transitions (EMT), fibroblasts and fibrocytes regulate collagen, and extracellular matrix (ECM) production. Epidermal stem cells (ESCs) and keratinocytes regulate epithelialization. Fibroblasts and proteolytic enzymes regulate remodeling in the final phase of wound healing. 
et al., 2009). During this phase mesenchymal stem cells (MSCs) migrate to the site of injury by responding to chemokine signaling molecules and regulate the healing process (Crisan et al., 2008; Riekstina et al., 2008; van Poll et al., 2008).

Angiogenesis, the formation of new capillaries from preexisting blood vessels, occurs by sprouting, intussusceptions (non-sprouting), and looping from pre-existing vessels (Bicknell and Harris, 2004; Gerritsen, 2008). The angiogenic switch, which stimulates new vessel formation is induced under conditions of hypoxia, low $\mathrm{pO}_{2}$, and mechanical stress (shear stress). Hypoxia induces angiogenesis through the hypoxia-inducible factor 1 (HIF-1) pathway with growth factor expression elevated in hypoxic conditions in a HIF dependent manner (Semenza, 2007). Macrophages, neutrophils, and fibroblasts all release growth factors which induce sprouting angiogenesis. Our laboratory has previously demonstrated increased angiogenesis between 2 and 24 weeks after surgery in human surgical wounds (Brown et al., 2002), which gradually reduced until 53 weeks after surgery, but failed to return to pre-surgery basal levels; microvessel density (MVD) was used as a surrogate marker of angiogenesis using both CD31 and CD34 markers (Kumar et al., 2009; Valluru et al., 2011).

Hematopoietic stem cell and endothelial precursor cells (EPC) share a common stem cell origin from hemangioblasts and are present in bone marrow (Gehling, 2006; Xiong, 2008; Lancrin et al., 2009). During vasculogenesis or angiogenesis, circulating and pre-existing EPC cells are attracted to the site of injury, and differentiate into endothelial cells (Asahara et al., 1999; Hill et al., 2003; Urbich and Dimmeler, 2004; Khakoo and Finkel, 2005), and research in our laboratory has demonstrated increased numbers of EPC found within blood vessels as early as 3 days post injury (Valluru et al., 2011).

Shortly after injury, basal keratinocytes in close proximity to the dermis migrate, proliferate, and differentiate into an epidermal layer at the site of repair. Basal keratinocytes act as keratinocyte stem cells, undergoing asymmetric cell division to form epidermal layers (Lechler and Fuchs, 2005; Clayton et al., 2007; Ambler and Määttä, 2009; Blanpain and Fuchs, 2009). Epidermal stem cells present in both the hair follicle region and the basal epidermal layer regulate epidermis formation by growth factors such as EGF, keratinocyte growth factor (KGF), TGF- $\alpha$, and TGF- $\beta$ from keratinocytes (Canic et al., 2004; Schultz, 2007).

\section{REMODELING}

Remodeling is the final phase of the wound healing process and involves blood vessel regression and removal of the granulation tissue by ECM remodeling and reconstruction (Dabiri and DiPersio, 2005). Fibroblasts and fibrocytes play important roles in ECM reconstruction, replacing old type III collagen with type I collagen, and cross linking the collagen molecules. Elastin fibers are also generated and the tensile strength of the wounded skin increases to that approaching normal skin, resulting in the final production of a scar (Hinz, 2007).

Therefore wound healing is dependent upon, and regulated by, a complex interaction of different cell types, growth factors (PDGF, TGF- $\beta$, TGF- $\alpha$, EGF, FGF, IGF-1) and their receptors, integrins, chemokines, cytokines, MMPs, tissue inhibitors of metalloproteinases (TIMP), proprotein convertase, and ECM components (Table 1). Moreover it is becoming apparent these different stem cell types may also act to either directly or indirectly regulate the

Table 1 | Regulators of the wound healing process.

\begin{tabular}{|c|c|c|c|c|c|c|c|}
\hline $\begin{array}{l}\text { Different stages of } \\
\text { wound healing }\end{array}$ & $\begin{array}{l}\text { Different stem } \\
\text { cells }\end{array}$ & $\begin{array}{l}\text { Different cell } \\
\text { types }\end{array}$ & $\begin{array}{l}\text { Growth factors } \\
\text { and cytokines }\end{array}$ & MMP & TIMP & Collagen & Integrins \\
\hline Hemostasis & $\begin{array}{l}\text { Hemangioblasts, hematopoietic } \\
\text { stem cells, endothelial progenitor } \\
\text { cells, mesenchymal stromal } \\
\text { cells/stem cells }\end{array}$ & Platelets & $\begin{array}{l}\text { PDGF, TGF- } \beta \text {, TGF- } \alpha, \\
\text { VEGF, IGF-1, and } \\
\text { bFGF }\end{array}$ & & & $\begin{array}{l}\text { Type I, III, V, VI, } \\
\text { XII, XIV }\end{array}$ & \\
\hline $\begin{array}{l}\text { Inflammatory } \\
\text { phase }\end{array}$ & Hematopoietic stem cells & $\begin{array}{l}\text { Monocytes } \\
\text { Neutrophils } \\
\text { Macrophages }\end{array}$ & $\begin{array}{l}\text { IL-1, IL-6, IL-8, PDGF, } \\
\text { TGF- } \beta, \text { TGF- } \alpha, \text { TNF- } \alpha \text {, } \\
\text { IFN- } \gamma, \text { IGF-1, and } \\
\text { FGF }\end{array}$ & $\begin{array}{l}\text { MMP-1, } \\
\text { MMP-8, } \\
\text { MMP-9, } \\
\text { MMP-12 }\end{array}$ & & & $\alpha 1 \beta 1$ \\
\hline \multirow{2}{*}{$\begin{array}{l}\text { Proliferative } \\
\text { phase: fibroblast } \\
\text { migration, matrix } \\
\text { mineralization, } \\
\text { angiogenesis, } \\
\text { granulation, } \\
\text { epithelialization }\end{array}$} & $\begin{array}{l}\text { Mesenchymal stromal cells/stem } \\
\text { cells, endothelial progenitor cells, } \\
\text { epidermal stem cells }\end{array}$ & Fibroblasts & $\begin{array}{l}\text { IL-1, PDGF, TGF- } \beta \text {, } \\
\text { TGF- } \alpha, \text { IGF-1, CTGF, } \\
\text { and EGF }\end{array}$ & $\begin{array}{l}\text { MMP-1, } \\
\text { MMP-2, } \\
\text { MMP-3, } \\
\text { MMP-7, }\end{array}$ & $\begin{array}{l}\text { TIMP-1, } \\
\text { TIMP-2, } \\
\text { TIMP-3, } \\
\text { TIMP-4 }\end{array}$ & $\begin{array}{l}\text { Type I, III, IV, V, } \\
\text { VI, VIII, XII, XIV, } \\
\text { XV, XVIII, XIX }\end{array}$ & $\begin{array}{l}\alpha 1, \alpha 2, \alpha 3, \\
\alpha 5\end{array}$ \\
\hline & & Keratinocytes & $\begin{array}{l}\text { EGF, KGF, TGF- } \beta \\
\text { bFGF, IGF, and TGF- } \alpha\end{array}$ & $\begin{array}{l}\text { MMP-1, } \\
\text { MMP-3, } \\
\text { MMP-9, } \\
\text { MMP-10 }\end{array}$ & & & $\begin{array}{l}\alpha 5 \beta 1, \alpha \vee \beta 5, \\
\alpha 2 \beta 1, \alpha \vee \beta 6, \\
\alpha 2, \alpha 5, \alpha 6\end{array}$ \\
\hline Remodeling & $\begin{array}{l}\text { Mesenchymal stromal cells/stem } \\
\text { cells }\end{array}$ & Fibroblasts & $\begin{array}{l}\text { PDGF, TGF- } \beta, \text { EGF, } \\
\text { and bFGF }\end{array}$ & & & $\begin{array}{l}\text { Type IV, VII, } \\
\text { XVII, XVIII, XIX }\end{array}$ & $\begin{array}{l}\alpha 1, \alpha 2, \alpha 3, \\
\alpha 5\end{array}$ \\
\hline
\end{tabular}


wound healing process. Although a plethora of factors are required for successful physiological tissue repair, TGF- $\beta$, and its receptors including Endoglin play an important role in all phases of the wound healing process.

\section{TRANSFORMING GROWTH FACTOR BETA SUPERFAMILY}

The TGF- $\beta$ Superfamily includes TGF- $\beta$ s $(1,2$, and 3$)$ with a molecular weight of $25-\mathrm{kDa}$, Activin (A, B, and AB), bone morphogenetic proteins (BMPs), and growth differentiation factors that bind to Type I, II, and III receptors with differential specificities; represented in Figure 2 (Lutz and Knaus, 2002; Groppe et al., 2008; Lonn et al., 2009; Moustakas and Heldin, 2009). TGF- $\beta$ signaling is mediated by canonical (Smad-dependent) and non-canonical (Smad-independent) mechanisms. The Smadindependent pathways include components of the Wnt, MAP kinase, phosphatidylinositol-3-kinase/AKT, and Rho-like GTPase signaling pathways (Kang et al., 2009; Zhang, 2009). The Smad family proteins (1-8) are molecules of $42-60 \mathrm{kDa}$, which are classified as receptor-regulated Smads (R-Smads: Smad1, 2, 4, 5, and 8), common mediator Smad (Co-Smad: Smad4), and inhibitory Smads (I-Smads: Smad6 and 7; Tao and Sampath, 2010).

Transforming growth factor betas regulate the phosphorylation of Smad family proteins (Wrighton et al., 2009; Liu and Feng, 2010). Phosphorylated R-Smads form both homomeric and heteromeric complexes with Co-Smad (Smad4) which accumulate in the nucleus and are involved in transcriptional regulation of target genes in cooperation with other transcription factors (Ross and Hill, 2008). Smad7 inhibits TGF- $\beta$ signaling by preventing activation of Smad 2 or Smad3, whereas Smad6 inhibits TGF- $\beta$ signaling by preventing activation of Smad1, Smad5, or Smad8 (Itoh and ten Dijke, 2007; Figure 2). Through their relevant signaling pathways TGF- $\beta$ s play important roles in regulating development, hemostasis, tissue regeneration, cell differentiation, proliferation, cell death and maintaining the stem cell state (Kitisin et al., 2007; Watabe and Miyazono, 2009; Pera and Tam, 2010).

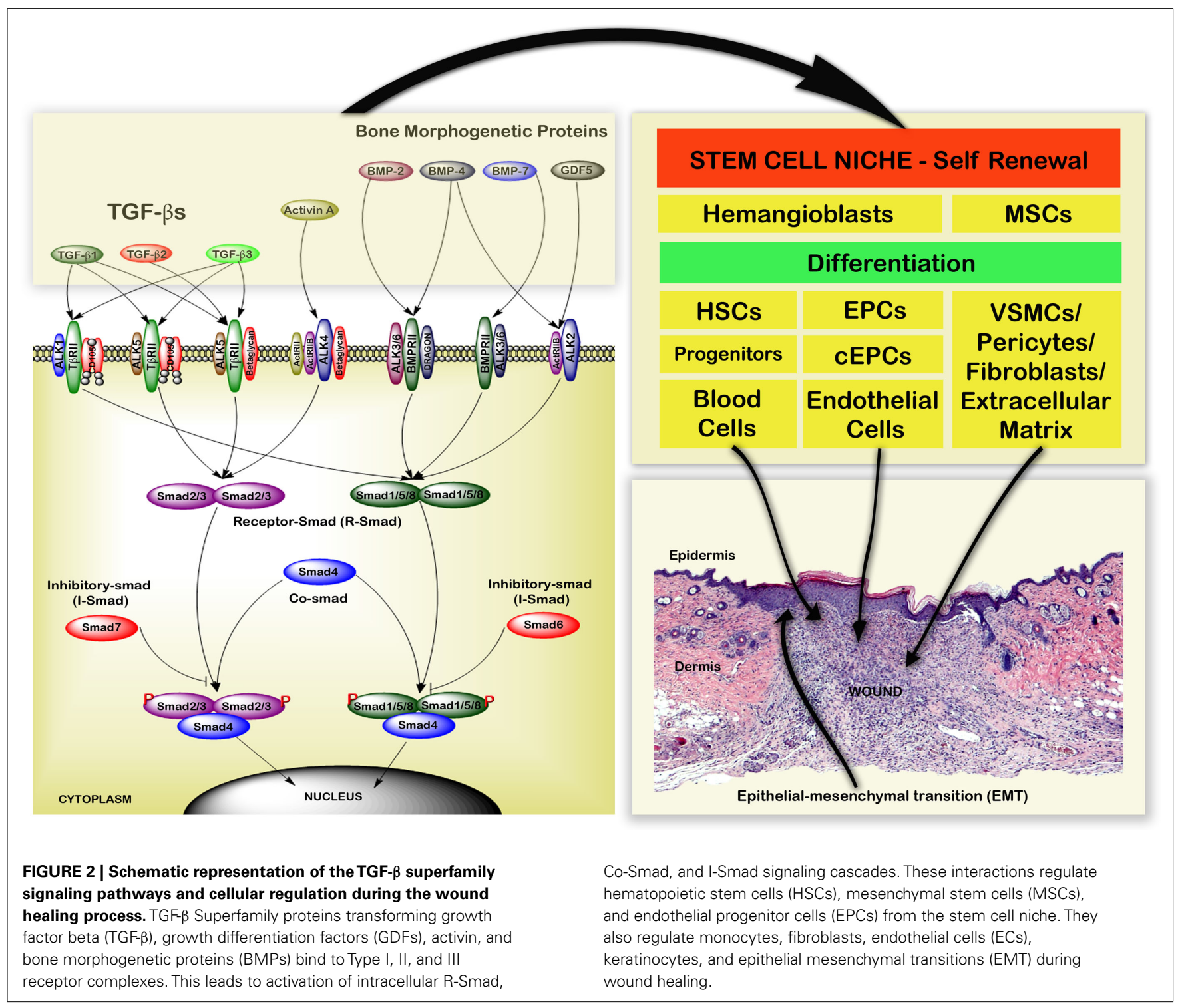




\section{THE ROLE OF TGF- $\beta$ IN WOUND HEALING TGF- $\beta$ isoforms}

Transforming growth factor beta is an important growth factor that regulates different cellular functions in all phases of wound healing (Table 1; Figure 2), including ECM production, protease expression, migration, chemotaxis, differentiation, and proliferation of different cell types (Faler et al., 2006; Klass et al., $2009)$. TGF- $\beta$ exists as three isoforms TGF- $\beta 1$, TGF- $\beta 2$, and TGF$\beta 3$. TGF- $\beta 1$ is important in inflammation, angiogenesis, regulates granulation tissue formation, extracellular matrix remodeling (Okuda et al., 1998), and is essential for re-epithelialization (Schmid et al., 1993). Whilst full thickness skin wounds in TGF$\beta 1$ knockout mice initially heal normally, mice die by 3-4 weeks of age due to an excessive inflammatory response and vascular defects (Shull et al., 1992; Kulkarni et al., 1993). Therefore TGF- $\beta 1$ knockouts were developed on an immunodeficient background which allowed study of wound healing in the absence of both TGF- $\beta 1$ and inflammation (Crowe et al., 2000). No appreciable differences were seen in the rate of healing between wild-type and heterozygous TGF- $\beta 1$ mice, but a significant delay in wound healing was observed in TGF- $\beta 1^{-/-}$mice. All stages of wound healing were affected, with delayed infiltration of inflammatory cells and angiogenesis in the wound bed, deficient granulation tissue formation, and decreased, unorganized apoptosis. It is interesting that wound healing was not delayed in the absence of TGF- $\beta 1$ or lymphocytes alone, but was when both were absent. It was suggested that this may be due to the delayed expression of TGF- $\beta 2$ and TGF- $\beta 3$ that occurs in the absence of TGF- $\beta 1$ (Crowe et al., $2000)$. TGF- $\beta 2$ is known to be involved in all stages of wound healing including stimulation of angiogenesis and the recruitment of inflammatory cells and fibroblasts to the wound site, thereby promoting the production of collagen (Wahl et al., 1987). Similarly TGF- $\beta 3$ has been shown to promote wound healing by recruiting inflammatory cells and fibroblasts to the wound site in addition to stimulating angiogenesis (Barrientos et al., 2008). Therefore a delayed expression of both may result in the observed phenotypes in immunodeficient TGF- $\beta 1$ knockout mice, but further work is required to confirm this hypothesis.

Wound-puncture fluids contain high levels of TGF- $\beta 1, \mathrm{KGF}$, VEGF, HGF, and MMP-1 (Aiba-Kojima et al., 2007). There is an increased frequency of CD41/TGF- $\beta 1$ producing $\mathrm{T}$ cells in the peripheral blood and hypertrophic scar tissue of burn patients (Wang et al., 2007a), and TGF- $\beta 1$ is a chemoattractant of inflammatory cells, recruiting monocytes to the wound site (Wahl et al., 1987). Higher levels of TGF- $\beta 1$ are produced by burn patient fibrocytes (Wang et al., 2007b).

\section{Regulation of stem cells and epithelial mesenchymal transitions by TGF- $\beta$}

In the initial phase of rat wound healing MMP-9 and TGF- $\beta$ expression regulate cell migration to promote the clearance of the inflammatory necrotic tissue (Zhu et al., 2005). TGF- $\beta$ s control hematopoiesis by regulating hemangioblasts and HSC proliferation (Turner et al., 1995; Ruscetti et al., 2005; Asmis et al., 2006; He et al., 2006). Indeed TGF- $\beta 1$ is a major regulator of HSC quiescence and TGF- $\beta 2$ positively regulates early HSCs function (Asmis et al., 2006). Skin also contains a reserve of skin-derived precursor
cells/MSCs (Riekstina et al., 2008). Cells with MSC markers also express pericyte markers, which harbor stem cells on blood vessel walls (Crisan et al., 2008). TGF- $\beta 1$ regulates the proliferation of MSCs by a non-canonical pathway involving crosstalk with the Wnt signaling pathway through Smad3 dependent nuclear translocation of $\beta$-catenin (Jian et al., 2006). TGF- $\beta 1$ induces increased smooth muscle actin expression and rapid differentiation in hMSCs (Hung et al., 2006). Epithelial mesenchymal transitions (EMT) occur during tissue repair and are regulated by TGF- $\beta 1$ via activation of the Erk signaling pathway (Xie et al., 2004; Thiery and Sleeman, 2006; Chapkin et al., 2008; Wu et al., 2008). A recent study demonstrated that EMT generates cells with stem-like properties (Mani et al., 2008) which may assist during tissue repair. TGF- $\beta 1$ also increases expression of MMP-2 and MMP-9 in airway epithelial cells (Lechapt-Zalcman et al., 2006) and our laboratory has previously shown elevated MMP-2 and MMP-9 levels associated with fibroblasts, during the angiogenic phase in early human dermal wound healing (Gillard et al., 2004). TGF- $\beta 2$ is required for normal collagen homeostasis (Thompson et al., 2006).

In humans, the expression of TGF- $\beta 1$ and TGF- $\beta 2$ is increased in wounds by day 7 , regulating scar contraction (Tian et al., 2000). TGF- $\beta 1$ modulates differentiation of fibroblasts into myofibroblasts via Rho GTPase activation (Shephard et al., 2004; Smith et al., 2006; Harvey et al., 2007; Wang et al., 2007b), regulating the migratory phenotype of the myofibroblasts, with increased $\alpha$ smooth muscle actin expression and contractile force generation in skin (Vaughan et al., 2000; Garrett et al., 2004; Padgett and Reiss, 2007). With upregulation of $\alpha$-smooth muscle actin expression there is a concomitant down-regulation of TGF- $\beta 1$ expression during wound healing (Ghassemifar et al., 1997).

\section{Angiogenesis}

The initial stages of angiogenesis during mouse corneal wound healing is induced by a non-angiogenic process involving myofibroblast contraction, followed by sprouting angiogenesis which is regulated by different growth factors (Kilarski et al., 2009). During development TGF- $\beta$ modulates vasculogenesis by regulating hemangioblasts and EPCs, and then plays an important role in angiogenesis (Bertolino et al., 2005), via activin like kinase 1 (ALK1) and ALK 5 (Type I receptor), T $\beta$ RII (Type II receptor), and Endoglin (Type III receptor) receptors leading to phosphorylation of cytoplasmic Receptor-Smad 1, 2, 3, and 5 (Bernabeu et al., 2007; Gomes et al., 2010). Migration and proliferation of tip and stalk endothelial cells is modulated through cross talk between TGF- $\beta$, VEGF and notch-mediated signaling (Holderfield and Hughes, 2008). Subsequently monocyte chemoattractant protein-1 (MCP-1) regulates vascular maturation by stimulating migration of vascular smooth muscle cells toward ECs via TGF- $\beta$ signaling (Ma et al., 2007).

\section{Re-epithelialization}

Transforming growth factor beta superfamily proteins are involved in the control of epidermal homeostasis, hair follicle growth, and melanogenesis (Botchkarev, 2003; Owens et al., 2008). Keratinocytes strongly express TGF- $\beta 1$ and TGF- $\beta 3$, and weakly express TGF- $\beta 2$ (Amjad et al., 2007). TGF- $\beta 3$ is involved in the 
maturation of scar tissue by regulating epidermal cell migration, collagen deposition, and cellular proliferation in rabbit wound healing (Nath et al., 1994; Tyrone et al., 2000; Bandyopadhyay et al., 2006). TGF- $\beta 1$ also promotes keratinocyte migration and reepithelialization in partial-thickness mice wounds (Tredget et al., 2005), via Smad2 signaling (Hosokawa et al., 2005).

In summary TGF- $\beta$ regulates many processes involved in tissue repair including production of ECM, proteases, protease inhibitors, migration, chemotaxis, and proliferation of macrophages, fibroblasts of the granulation tissue, epithelial, and capillary endothelial cells. TGF- $\beta$ also plays an important role in regulating differentiation of HSC, MSC, EPC in addition to EMT (Figure 2).

\section{THE ROLE OF ENDOGLIN (CD105) IN WOUND HEALING ENDOGLIN STRUCTURE}

Endoglin is a type III auxillary coreceptor (T $\beta$ RIII) for T $\beta$ RII, ALK1 and activin like kinase 5 (ALK5), and interacts with other TGF- $\beta$ family members (Figure 3). L-Endoglin and S-Endoglin are two splice variants of Endoglin (ten Dijke et al., 2008; Le et al., 2009). L-Endoglin is a 68,051 Da homodimeric transmembrane glycoprotein with a 561 amino acid extracellular domain, 25 amino acid membrane domain, and a 47 amino acid cytoplasmic tail (Gougos and Letarte, 1990). Dimeric S-Endoglin is a $70 \mathrm{kDa}$ protein with the maximum longitudinal dimension of $170 \AA$ (Le et al., 2009). L-Endoglin C-terminus contains a PDZbinding motif (SerSerMetAla) which is an important determinant of Rho guanine exchange factor function and cell phenotype, and is absent in S-Endoglin (Liu and Horowitz, 2006; Bernabeu et al., 2007). S-Endoglin leads to dysregulated TGF- $\beta$ signaling in the vasculature by activation of eNOS and vasodilation (Venkatesha et al., 2006).

Endoglin is expressed on a number of cell types including proliferating endothelial cells, activated monocytes, tissue macrophages, stromal cells, pre-B cells, erythroid precursors, syncytiotrophoblast, cytotrophoblasts, and tumor cells (Gougos and Letarte, 1990; Dallas et al., 2008). Mutations in the Endoglin gene can lead to hereditary hemorrhagic telangiectasia (HHT) and defective angiogenesis (Llorca et al., 2007; ten Dijke et al., 2008). TGF- $\beta 1$, TGF- $\beta 2$, TGF- $\beta 3$, activin, BMP-2, and BMP-7 bind to Endoglin by association with the TGF- $\beta$ type II receptor (Figure 3; Barbara et al., 1999). In myoblasts L-Endoglin regulates the TGF$\beta / A L K 1$ pathway and S-Endoglin regulates TGF- $\beta$ /ALK5 pathway (ten Dijke et al., 2008).

It is well known that hypoxic conditions occur during wound healing. Hypoxia controls angiogenic growth factor and cytokine production, in addition to inducing Endoglin expression through the HIF-1 and p38 pathways (Guo et al., 2004a). The TGF- $\beta 1$, p38 and JNK pathways also regulate Endoglin mRNA and protein levels (Zhu et al., 2003). The Endoglin promoter region contains binding sites for the multiprotein complex Sp1.Smad3.HIF-1 which regulates cross talk between hypoxia and TGF- $\beta$ pathways, with basal Endoglin transcription highly dependent on $\mathrm{Sp} 1$ interaction with other factors (Sánchez-Elsner et al., 2002). TGF- $\beta$ /Endoglin mediated signaling during hypoxia inhibits cell apoptosis by caspase 3 and 8 inhibition (Li et al., 2003). Caspases 3 and 8 contribute to cell death and promote wound healing, and mice deficient in caspases
3 and 8 demonstrated delayed dermal wound healing (Lee et al., 2009; Li et al., 2010).

\section{ENDOGLIN REGULATION OF CELL FUNCTION}

Endoglin, in combination with TGF- $\beta$ family members, plays an important role in regulating different cellular functions. Endoglin interaction with zyxin, ZRP-1, tctex $2 \mathrm{~b}$, and arrestin proteins regulate endothelial cell adhesion, migration, and proliferation (Conley et al., 2004; Bernabeu et al., 2007). Interaction of Endoglin with TGF- $\beta 1$ mediated by the type I TGF- $\beta$ receptor ALK5, upregulates cytoplasmic Smad2 levels leading to endothelial nitric oxide synthase (eNOS) expression, which is involved in regulating vascular function (Santibanez et al., 2007). Endoglin also interacts with a scaffolding protein, GAIP-interacting protein C (GIPC), which is mediated by a class I PDZ-binding motif in the cytoplasmic domain. Endoglin co-localizes with GIPC and enhances TGF- $\beta 1$ induced phosphorylation of Smad1/5/8 (Lee et al., 2008). Endoglin promotes ACVRL1 (activin A receptor type II-like 1) induced phosphorylation of Smad1/5/8 (Mahmoud et al., 2009), enhancing endothelial cell growth and adhesion.

Interaction between Endoglin and the scaffold protein $\beta$ arrestin2 enhances internalization of Endoglin by endocytosis. This process is ALK1 dependent and inhibits TGF- $\beta$ mediated ERK signaling (Lee and Blobe, 2007), resulting in decreased endothelial cell migration, thus is likely to be important during angiogenesis. These studies show that Endoglin regulates a number of cell functions such as cell adhesion, migration, permeability, apoptosis and proliferation in a variety of cell types (Figure 3).

\section{ENDOGLIN AND STEM CELLS}

Due to the important role Endoglin plays in a number of cellular processes and the elevated expression during wound healing, Endoglin appears likely to have a central role in this process (Torsney et al., 2002; Figure 4). Different cell types such as monocytes, neutrophils, and stem cells regulate the inflammatory phase. Endoglin is functional marker for long term repopulating HSCs (Endoglin ${ }^{\text {Positive }}$ Sca-1 ${ }^{\text {Positive }}$ Rhodamine ${ }^{\text {Low }}$; Chen et al., 2003). Some experimental studies have shown that Endoglin is highly expressed in megakaryocyte-erythroid progenitors, with lower expression in granulocyte-macrophage progenitors, and common myeloid progenitors, which gradually reduces in mature cell types (mature granulocytes and Ter119+ erythroid cells; Pronk et al., 2007). Endoglin is also expressed in inflammatory cells including macrophages and T cells (Torsney et al., 2002). Thrombin is involved in the coagulation cascade and converts soluble fibrinogen into insoluble strands of fibrin and is inactivated by antithrombin and serine protease inhibitors. Thrombin activated protease-activated receptor 1 (PAR1), induces endocytosis of Endoglin and T $\beta$ RII, thereby down regulating TGF- $\beta$ signaling in endothelial cells, demonstrating the role of thrombin in regulating angiogenesis (Tang et al., 2005).

Absence of Endoglin ( $\mathrm{Eng}^{-/-}$) results in a reduction in hemangioblasts and decreases the cell number with hematopoietic potential, thus demonstrating the requirement and importance of Endoglin for hemangioblast and early hematopoietic development (Perlingeiro, 2007). Endoglin is highly expressed in MSCs but this gradually reduces with increased differentiation potential, with no 


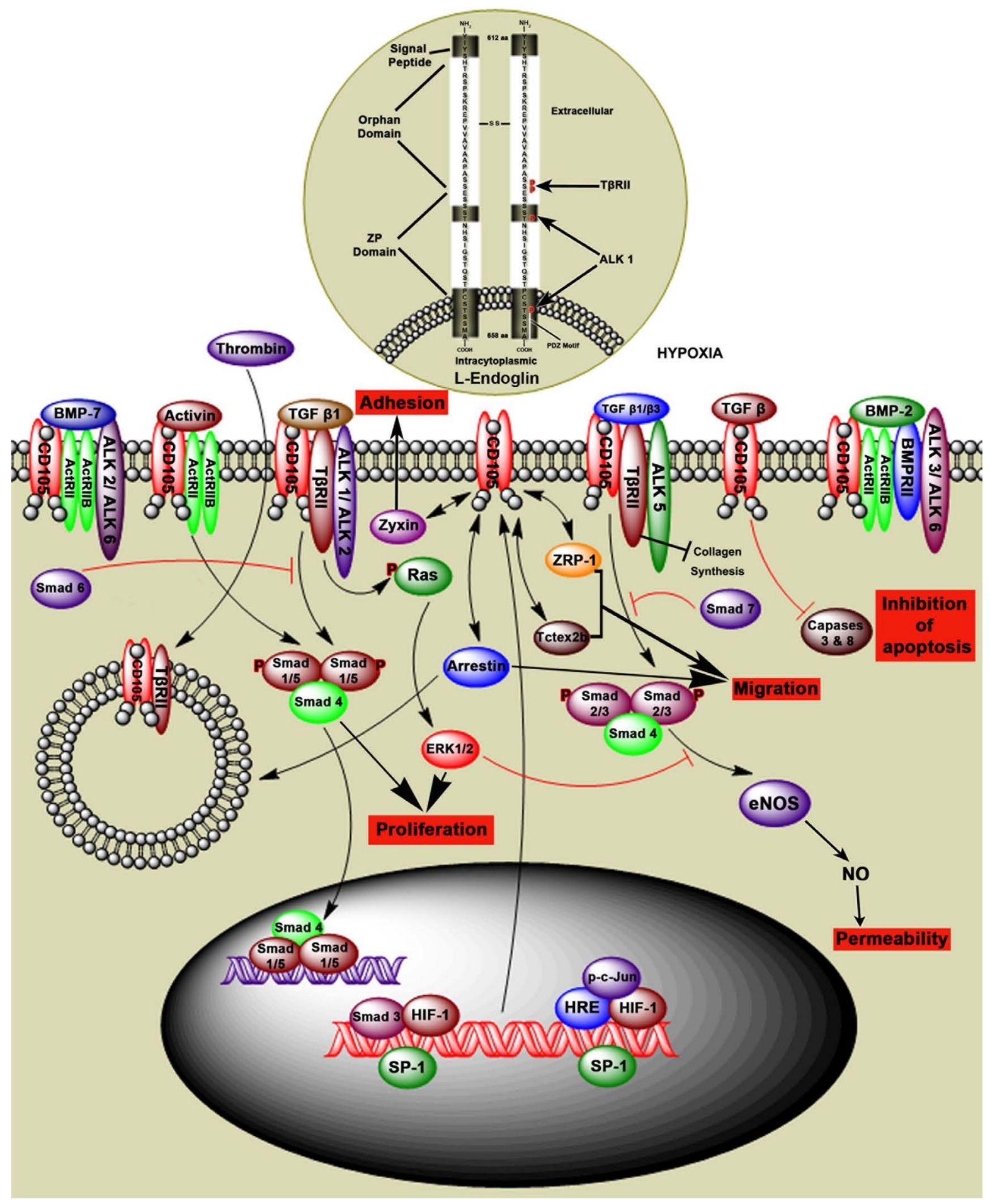

FIGURE 3 | Hypothetical model of Endoglin structure and function. Endoglin, also called CD105, is a type III auxiliary coreceptor (TRRIII). L-Endoglin and S-Endoglin are two isoforms of Endoglin. L-Endoglin shown in this figure is a $68,051 \mathrm{Da}$ homodimeric transmembrane glycoprotein that binds to TGF- $\beta 1$, TGF- $\beta 2$, activin, BMP-2, and BMP-7 by associating with the TGF- $\beta$ type II receptors (ActRII, ActRIIB, ALK1, ALK2, ALK3, ALK5, ALK6, BMPRII, and T $\beta R$ II). Intranuclear events show that Sp1 regulates Endoglin transcription by interacting with other factors in the hypoxic environment.
TGF- $\beta 1$ and $\beta 3$ regulate intracellular Smads (Smad1/5, Smad 2/3, and Smad4) via the TGF- $\beta$ receptor complex, which regulates cell proliferation, adhesion, and permeability. Intracytoplasmic events show that Smad6 inhibits phosphorylation of Smad1/5 and Smad7 inhibits phosphorylation of Smad2/3. TGF- $\beta$ signaling through Endoglin induces inhibition of caspases 3 and 8 and therefore inhibition of apoptosis. Endoglin interaction with ZRP-1, Zyxin, and Tctex $2 \mathrm{~b}$ regulates cell adhesion and migration. Thrombin induces internalization of Endoglin TGF- $\beta$ RII complex by endocytosis. 


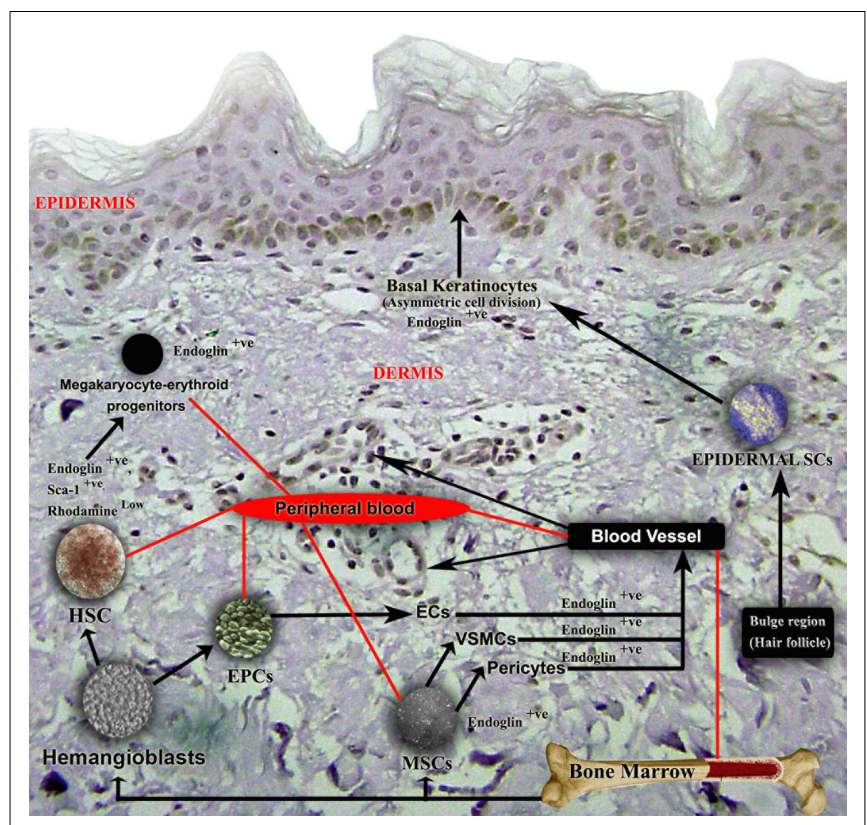

FIGURE 4 | Schematic representation of Endoglin expression in different cell types during the wound healing process. Endoglin is expressed on stem cells and proliferating cells, and is an expression marker for MSCs, HSCs, and megakaryocyte-erythroid progenitors. Eng +9 and Eng+7 function as potent hematoendothelial enhancers and Endoglin is expressed in proliferating endothelial cells, VSMCs, pericytes, and basal keratinocytes. The functional role of endoglin on all these cell types in wound healing is not currently well understood.

expression seen on differentiated cells (Jin et al., 2009). Circulating Endoglin expressing mesenchymal progenitor cells are also present in normal individuals (Zvaifler et al., 2000), and the percentage of MSCs (Endoglin positive, CD44+, CD13+, CD29+, and CD90+) is increased during burn injury (Mansilla et al., 2006), suggesting a role during healing.

\section{ANGIOGENESIS}

Endoglin is highly expressed on proliferating endothelial cells and pericytes during angiogenesis (Crisan et al., 2008; Dallas et al., 2008), with increased Endoglin expression observed in blood vessels between days 2 and 28 of wound healing (Torsney et al., 2002). Studies in our laboratory have also demonstrated elevated Endoglin expression in blood vessels in surgical wounds from as early as 3 days post surgery until 24 weeks post surgery (Valluru et al., 2011). Genetic disruption of TGF $\beta 1$, its T $\beta$ RII and Endoglin lead to VSMC/pericyte differentiation defects resulting in cardiovascular failure and subsequent embryonic lethality (ten Dijke et al., 2008). Indeed Endoglin knockout mice die in utero (day 10.5) and fail to form mature blood vessels in the yolk sac whereas Endoglin ${ }^{+/-}$mice demonstrate significant defects in vascular repair (van Laake et al., 2006), although wound healing has yet to be investigated in these animals.

Endoglin may also play an important role in the angiogenic process by regulating endothelial tip and stalk cells, and appears to have a pivotal role in blood cell mediated vascular repair (van Laake et al., 2006). Endoglin regulated through TGF- $\beta$ /ALK1 signaling induces phosphorylation of Smad1/5/8 which results in endothelial cell proliferation (Lebrin et al., 2004). In contrast Endoglin signaling through TGF- $\beta$ /ALK5, induces Smad $2 / 3$ phosphorylation and regulates cellular permeability (Bernabeu et al., 2007). Endoglin, T $\beta$ RII and ALK1/ALK2 receptor complexes regulate the phosphorylation of Ras and activated ERK1/2. ERK1/2 and JNK1 may inhibit the Smad2/3 signaling activated by the Endoglin, T $\beta$ RII and ALK5 receptor complex (Guo et al., 2004b). Downstream signaling of Smad2/3 promotes cell growth. ALK1 is the preferred TGF $\beta$ receptor for Endoglin threonine phosphorylation in HUVECs (Lebrin et al., 2004; Koleva et al., 2006). Expression of Endoglin is also observed on perivascular cells, and during long term culture, cells express MSC markers and exhibit differentiation potential (Crisan et al., 2008). In addition an increased Endoglin expression has been observed in vascular smooth muscle cells in human atherosclerotic plaques (Conley et al., 2000; Bot et al., 2009). These studies demonstrate that Endoglin may have a role in maintenance of vascular integrity in response to injury.

\section{FIBROBLASTS AND RE-EPITHELIALIZATION}

Fibroblasts play an important role in fibroplasia and granulation tissue formation during wound healing, with significant elevation in fibroblast-associated Endoglin levels observed between days 4 and 10 of wound healing (Torsney et al., 2002). Fibroblast cells expressing Endoglin demonstrate myogenic differentiation potential in vivo (Conconi et al., 2006). However we have been unable to demonstrate an elevation in Endoglin expression in human wound fibroblasts.

During epithelialization, homeostasis is regulated by skin or epidermal stem cells located at the bulge region of the hair follicle, keratinocytes of the interfollicular epidermis, and the sebaceous glands. During both wound healing and skin homeostasis, epidermal stem cells from the bulge region migrate to the hair follicle region, the epidermal basal keratinocyte region and the sweat glands (Morasso and Tomic-Canic, 2005; Ambler and Määttä, 2009; Blanpain and Fuchs, 2009). Experimental studies have shown Endoglin expression in unwounded human epidermis (basal keratinocytes) and skin appendages (hair bulb keratinocytes), suggesting Endoglin may attenuate TGF- $\beta 1$ signaling in normal epidermis. Keratinocytes interact with fibroblasts in a TGF- $\beta$ dependent manner during the wound healing process (Werner et al., 2007) and some studies have shown that the mesenchymal and epithelial interaction in skin is crucial for homeostasis and regeneration (Yuji et al., 2005).

In summary, Endoglin is expressed in a broad spectrum of proliferating cells and stem cells, regulating important cellular functions that are involved in the wound healing process (Figure 4).

\section{FUTURE DIRECTIONS}

Transforming growth factor beta plays a critical role in the different phases of wound healing by regulating production of ECM, proteases, protease inhibitors, migration, chemotaxis, and proliferation of different cell types including stem cells, which regulate scar contraction, angiogenesis, granulation tissue formation, extracellular matrix remodeling, and scar maturation. TGF- $\beta$ binds to the TGF- $\beta$ receptor complex and regulates intracellular cascades. 
Endoglin is a member of TGF- $\beta$ receptor complex which is highly expressed in a number of proliferating cell types and differentiating stem cells, during the initial phase of wound healing. Endoglin is not only a proliferation marker but also regulates cellular functions such as cell adhesion, migration, and permeability. Indeed Endoglin may play an important role in regulating the mobilization of stem cells from a specific niche to the wounded region. Endoglin and TGF- $\beta$ are also highly expressed in pathological conditions that demonstrate an amplified inflammatory environment and increased angiogenesis, such as fibrosis, atherosclerotic plaques, and metastatic cancer (Nikiteas et al., 2007; Oxmann et al., 2008; Meurer et al., 2011). Although the exact mechanisms have yet to be identified, in these pathological conditions TGF- $\beta$ and Endoglin are thought to be involved in similar pathways to those described in wound healing, resulting in increased ECM production, protease expression, migration, chemotaxis, proliferation, and differentiation of different cell types including endothelial and tumor cells. An increased understanding of the functional role of TGF $\beta$ and Endoglin in physiological wound healing, may therefore also provide insight into their importance in pathology. Importantly, in these disease states, inflammation and angiogenesis are not controlled, unlike tissue repair, where a physiological balance occurs and there is regulated control. Improving our knowledge of the functional role of these proteins may identify therapeutic targets for the treatment of abnormal wound healing and pathological inflammatory and angiogenesis-dependent conditions.

To allow the potential development of TGF- $\beta$ and Endoglin targeted therapy it is necessary to fully evaluate their function using in vivo wound healing models. The murine incisional wound model demonstrates complete wound healing, and remodeling is accomplished within 4 weeks (Sandlund et al., 2006), whereas in humans the remodeling phase is incomplete even after 12 months (Brown et al., 2002; Gillard et al., 2004; Kumar et al., 2009). Although the process is much shorter than in humans, the murine incisional wound model demonstrates the same phases and patterns of markers identified in normal human wound healing (Sandlund et al., 2006) and is therefore an extremely useful model. Indeed, the application of mechanical loading to this model results in increased fibrosis, similar to human hypertrophic scars (Aarabi

\section{REFERENCES}

Aarabi, S., Bhatt, K. A., Shi, Y., Paterno, J., Chang, E. I., Loh, S. A., Holmes, J. W., Longaker, M. T., Yee, H., and Gurtner, G. C. (2007). Mechanical load initiates hypertrophic scar formation through decreased cellular apoptosis. FASEB J. 21, 3250-3261.

Aiba-Kojima, E., Tsuno, N. H., Inoue, K., Matsumoto, D., Shigeura, T., Sato, T., Suga, H., Kato, H., Nagase, T., Gonda, K., Koshima, I., Takahashi, K., and Yoshimura, K. (2007). Characterization of wound drainage fluids as a source of soluble factors associated with wound healing: comparison with platelet-rich plasma and potential use in cell culture. Wound Repair Regen. 15, 511-520.
Ambler, C. A., and Määttä, A. (2009). Epidermal stem cells: location, potential and contribution to cancer. J. Pathol. 217, 206-216.

Amjad, S. B., Carachi, R., and Edward, M. (2007). Keratinocyte regulation of TGF-beta and connective tissue growth factor expression: a role in suppression of scar tissue formation. Wound Repair Regen. 15, 748-755.

Asahara, T., Masuda, H., Takahashi, T., Kalka, C., Pastore, C., Silver, M., Kearne, M., Magner, M., and Isner, J. M. (1999). Bone marrow origin of endothelial progenitor cells responsible for postnatal vasculogenesis in physiological and pathological neovascularization. Circ. Res. 85, 221-228.

et al., 2007), enabling a comparison between normal and pathological wound healing. Studying functional angiogenesis in normal wound healing, can be achieved by adaptation of the dorsal skinfold chamber model (Bingle et al., 2006) to include a wound incision, in combination with intravital microscopy which allows the assessment of angiogenesis, vessel function, and blood flow, in response to application of different inhibitors (Machado and Mitchell, 2011). The roles of TGF- $\beta$ and Endoglin in wound healing need to be evaluated in appropriate in vivo models on a knockout/specific cell type knockdown background (see TGF- $\beta$ Isoforms) and/or in combination with targeted inhibitors. In this manner it will be possible to establish when and how TGF- $\beta$ and/or Endoglin may be targeted as a potential therapy.

As TGF- $\beta$ signaling is involved in a multitude of different pathways and expressed on a variety of cell types, despite evidence that TGF- $\beta 1$ knockout will result in delayed wound healing and impaired angiogenesis (Crowe et al., 2000), it is extremely unlikely that systemic inhibitors directly targeting TGF- $\beta 1$ will be of therapeutic use due to the large potential for side effects. It is possible that burns patients developing hypertrophic scars, which demonstrate increased TGF- $\beta$ expression and a subsequent excess of angiogenesis and fibrosis (Wang et al., 2007b), may benefit from local application of a specific TGF- $\beta$ inhibitor. However, it is more likely that targeting a specific downstream signaling pathway may have therapeutic potential, especially in metastatic cancer where localized treatment is extremely difficult, and therefore further work is required to elucidate which of the plethora of downstream signals will be of key importance. Endoglin has a more restricted expression pattern, so targeting with specific inhibitors is likely to cause fewer side effects than TGF- $\beta$ inhibitors. However, further work is required to establish the signaling pathways associated with Endoglin and the effects of specifically inhibiting this receptor molecule, as although understanding of the mechanisms of actions of Endoglin has significantly increased in recent years, the exact signaling pathways involved require definition.

\section{ACKNOWLEDGMENTS}

This work was supported by the Sheffield Hospitals Charitable Trust.

Asmis, R., Qiao, M., Rossi, R. R. Cholewa, J., Xu, L., and Asmis, L. M. (2006). Adriamycin promotes macrophage dysfunction in mice. Free Radic. Biol. Med. 41, 165-174.

Bandyopadhyay, B., Fan, J., Guan, S. Li, Y., Chen, M., Woodley, D. T., and Li, W. (2006). A "traffic control" role for TGF $\beta 3$ : orchestrating dermal and epidermal cell motility during wound healing. J. Cell Biol. 172, 1093-1105.

Barbara, N. P., Wrana, J. L., and Letarte, M. (1999). Endoglin is an accessory protein that interacts with the signaling receptor complex of multiple members of the transforming growth factor- $\beta$ superfamily. J. Biol. Chem. 274, 584-594.
Barrientos, S., Stojadinovic, O., Golinko, M. S., Brem, H., and Tomic-Canic, M. (2008). Growth factors and cytokines in wound healing. Wound Repair Regen. 16, 585-601.

Bernabeu, C., Conley, B. A., and Vary, C. P. H. (2007). Novel biochemical pathways of endoglin in vascular cell physiology. J. Cell. Biochem. 102, 1375-1388.

Bertolino, P., Deckers, M., Lebrin, F., and ten Dijke, P. (2005). Transforming growth factor-beta signal transduction in angiogenesis and vascular disorders. Chest 128, 585S-590S.

Bicknell, R., and Harris, A. L. (2004). Novel angiogenic signaling pathways and vascular targets. Annu. Rev. Pharmacol. Toxicol. 44, 219-238. 
Bingle, L, Lewis, C. E., Corke, K. P., and Reed, M. W. R. Brown NJ. (2006). Macrophages promote angiogenesis in human breast tumour spheroids in vivo. Br. J. Cancer 94, 101-107.

Blanpain, C., and Fuchs, E. (2009). Epidermal homeostasis: a balancing act of stem cells in the skin. Nat. Rev. Mol. Cell Biol. 10, 207-217.

Bot, P. T. G., Hoefer, I. E., Sluijter, J. P. G., van Vliet, P., Smits, A. M., Lebrin, F., Moll, F., de Vries, J.-P., Doevendans, P., Piek, J. J., Pasterkamp, G., and Goumans, M. J. (2009). Increased expression of the transforming growth factor-\{beta\} signaling pathway, endoglin, and early growth response-1 in stable plaques. Stroke 40, 439-447.

Botchkarev, V. A. (2003). Bone morphogenetic proteins and their antagonists in skin and hair follicle biology. J. Invest. Dermatol. 120, 36-47.

Brown, N. J., Smyth, E. A. E., Cross, S. S., and Reed, M. W. R. (2002). Angiogenesis induction and regression in human surgical wounds. Wound Repair Regen. 10, 245-251.

Canic, M. T., Ågren, M. S., and Alvarez, O. M. (2004). "Epidermal repair and the chronic wound," in The Epidermis in Wound Healing, eds D. T. Rovee and H. I. Maibach (Boca Raton, FL: CRC Press LLC), 25-58.

Chapkin, R. S., Wang, N., Fan, Y. Y., Lupton, J. R., and Prior, I. A. (2008). Docosahexaenoic acid alters the size and distribution of cell surface microdomains. Biochim. Biophys. Acta 1778, 466-471.

Chen, C.-Z., Li, L., Li, M., and Lodish, H. F. (2003). The endoglin positive scalpositive rhodaminelow phenotype defines a near-homogeneous population of long-term repopulating hematopoietic stem cells. Immunity 19, 525-533.

Clayton, E., Doupe, D. P., Klein, A. M., Winton, D. J., Simons, B. D., and Jones, P. H. (2007). A single type of progenitor cell maintains normal epidermis. Nature 446, 185-189.

Conconi, M. T., Burra, P., Di Liddo, R., Calore, C., Turetta, M., Bellini, S., Bo, P., Nussdorfer, G. G., and Parnigotto, P. P. (2006). CD105(+) cells from Wharton's jelly show in vitro and in vivo myogenic differentiative potential. Int. J. Mol. Med. 18, 1089-1096.

Conley, B. A., Koleva, R., Smith, J. D., Kacer, D., Zhang, D., Bernabéu, C., and Vary, C. P. H. (2004). Endoglin controls cell migration and composition of focal adhesions: function of the cytosolic domain. J. Biol. Chem. 279, 27440-27449.

Conley, B. A., Smith, J. D., GuerreroEsteo, M., Bernabeu, C., and Vary,
C. P. (2000). Endoglin, a TGFbeta receptor-associated protein, is expressed by smooth muscle cells in human atherosclerotic plaques. Atherosclerosis 153, 323-335.

Crisan, M., Yap, S., Casteilla, L., Chen, C., Corselli, M., Park, T., Andriolo, G., Sun, B., Zheng, B., and Zhang, L. (2008). A perivascular origin for mesenchymal stem cells in multiple human organs. Cell Stem Cell 3, 301-313.

Crowe, M. J., Doetschman, T., and Greenhalgh, D. G. (2000). Delayed wound healing in immunodeficient TGF-[beta]1 knockout mice. 115, 3-11.

Dabiri, G., and DiPersio, C. M. (2005). "Matrix metalloproteinases (MMPs)," in Wound Healing, eds A. F. Falabella and R. S. Kirsner (Boca Raton: Taylor and Francis Group), 49-56.

Dallas, N. A., Samuel, S., Xia, L., Fan, F., Gray, M. J., Lim, S. J., and Ellis, L. M. (2008). Endoglin (CD105): a marker of tumor vasculature and potential target for therapy. Clin. Cancer Res. 14, 1931-1937.

Faler, B. J., Macsata, R. A., Plummer, D., Mishra, L., and Sidawy, A. N. (2006). Transforming growth factor\{beta\} and wound healing. Perspect. Vasc. Surg. Endovasc. Ther. 18, 55-62.

Garrett, Q., Khaw, P. T., Blalock, T. D., Schultz, G. S., Grotendorst, G. R., and Daniels, J. T. (2004). Involvement of CTGF in TGF-\{beta 1 stimulation of myofibroblast differentiation and collagen matrix contraction in the presence of mechanical stress. Invest. Ophthalmol. Vis. Sci. 45, 1109-1116.

Gehling, U. M. (2006). Hemangioblasts and their progeny. Methods Enzymol. 419, 179-193.

Gerritsen, M. E. (2008). “Angiogenesis,” in Handbook of Physiology: Microcirculation, eds R. F. Tuma, W. N. Duran, and K. Ley (Cambridge, MA: Elsevier Science), 351-372.

Ghassemifar, M., Tarnuzzer, R., Chegini, N., Tarpila, E., Schultz, G., and Franzén, L. (1997). Expression of alpha-smooth muscle actin, TGF- $\beta 1$ and TGF- $\beta$ type II receptor during connective tissue contraction. In vitro Cell. Dev. Biol.- Anim. 33, 622-627.

Gillard, J. A., Reed, M. W. R., Buttle, D., Cross, S. S., and Brown, N. J. (2004). Matrix metalloproteinase activity and immunohistochemical profile of matrix metalloproteinase2 and -9 and tissue inhibitor of metalloproteinase-1 during human dermal wound healing. Wound Repair Regen. 12, 295-304.
Gomes, I., Dale, C. S., Casten, K. Geigner, M. A., Gozzo, F. C., Ferro, E. S., Heimann, A. S., and Devi, L. A. (2010). Hemoglobin-derived peptides as novel type of bioactive signaling molecules. AAPS J. 12, 658-669.

Gougos, A., and Letarte, M. (1990). Primary structure of endoglin, an RGDcontaining glycoprotein of human endothelial cells. J. Biol. Chem. 265, 8361-8364.

Groppe, J., Hinck, C. S., SamavarchiTehrani, P., Zubieta, C., Schuermann, J. P., Taylor, A. B., Schwarz, P. M., Wrana, J. L., and Hinck, A. P. (2008). Cooperative assembly of TGF-beta superfamily signaling complexes is mediated by two disparate mechanisms and distinct modes of receptor binding. Mol. Cell 29, 157-168.

Guo, B., Kumar, S., Li, C., Slevin, M., and Kumar, P. (2004a). CD105 (endoglin), apoptosis, and stroke. Stroke 35, e94-e95.

Guo, B., Slevin, M., Li, C., Parameshwar, S., Liu, D., Kumar, P., Bernabeu, C., and Kumar, S. (2004b). CD105 inhibits transforming growth factorbeta-Smad3 signalling. Anticancer Res. 24, 1337-1345.

Gurtner, G. C., Werner, S., Barrandon, Y., and Longaker, M. T. (2008) Wound repair and regeneration. Nature 453, 314-321.

Harvey, K. A., Paranavitana, C. N., Zaloga, G. P., and Siddiqui, R. A. (2007). Diverse signaling pathways regulate fibroblast differentiation and transformation through Rho kinase activation. J. Cell. Physiol. 211, 353-363.

He, W., Dorn, D. C., ErdjumentBromage, H., Tempst, P., Moore, M. A., and Massague, J. (2006). Hematopoiesis controlled by distinct TIFlgamma and Smad4 branches of the TGFbeta pathway. Cell 125, 929-941.

Hill, J. M., Zalos, G., Halcox, J. P. J., Schenke, W. H., Waclawiw, M. A., Quyyumi, A. A., and Finkel, T. (2003). Circulating endothelial progenitor cells, vascular function, and cardiovascular risk. N. Engl. J. Med. 348, 593-600.

Hinz, B. (2007). Formation and function of the myofibroblast during tissue repair. J. Invet. Dermatol. 127, 526-537.

Holderfield, M. T., and Hughes, C. C. W. (2008). Crosstalk between vascular endothelial growth factor, notch, and transforming growth factor\{beta\} in vascular morphogenesis. Circ. Res. 102, 637-652.

Hosokawa, R., Urata, M. M., Ito, Y., Bringas, P., and Chai, Y. (2005).
Functional significance of $\operatorname{Smad} 2$ in regulating basal keratinocyte migration during wound healing. J. Invest. Dermatol. 125, 1302-1309.

Hung, S. C., Kuo, P. Y., Chang, C. F., Chen, T. H., and Ho, L. L. (2006). Alpha-smooth muscle actin expression and structure integrity in chondrogenesis of human mesenchymal stem cells. Cell Tissue Res. 324, 457-466.

Itoh, S., and ten Dijke, P. (2007). Negative regulation of TGF-beta receptor/Smad signal transduction. Curr. Opin. Cell Biol. 19, 176-184.

Jian, H., Shen, X., Liu, I., Semenov, M., He, X., and Wang, X. F. (2006). Smad3-dependent nuclear translocation of beta-catenin is required for TGF-betal-induced proliferation of bone marrow-derived adult human mesenchymal stem cells. Genes Dev. 20, 666-674.

Jin, H. J., Park, S. K., Oh, W., Yang, Y. S., Kim, S. W., and Choi, S. J. (2009). Down-regulation of CD105 is associated with multi-lineage differentiation in human umbilical cord blood-derived mesenchymal stem cells. Biochem. Biophys. Res. Commun. 381, 676-681.

Kang, J. S., Liu, C., and Derynck, R. (2009). New regulatory mechanisms of TGF-beta receptor function. Trends Cell Biol. 19, 385-394.

Khakoo, A. Y., and Finkel, T. (2005). Endothelial progenitor cells. Annu. Rev. Med. 56, 79-101.

Kilarski, W. W., Samolov, B., Petersson, L., Kvanta, A., and Gerwins, P. (2009). Biomechanical regulation of blood vessel growth during tissue vascularization. Nat. Med. 15, 657-664.

Kimmel, A. R., Brasaemle, D. L., McAndrews-Hill, M., Sztalryd, C., and Londos, C. (2010). Adoption of PERILIPIN as a unifying nomenclature for the mammalian PAT-family of intracellular lipid storage droplet proteins. J. Lipid Res. 51, 468-471.

Kitisin, K., Saha, T., Blake, T., Golestaneh, N., Deng, M., Kim, C., Tang, Y., Shetty, K., Mishra, B., and Mishra, L. (2007). TGF-beta signaling in development. Sci. STKE 2007, cml.

Klass, B. R., Grobbelaar, A. O., and Rolfe, K. J. (2009). Transforming growth factor $\beta 1$ signalling, wound healing and repair: a multifunctional cytokine with clinical implications for wound repair, a delicate balance. Postgrad. Med. J. 85, 9-14.

Koleva, R. I., Conley, B. A., Romero, D., Riley, K. S., Marto, J. A., Lux, A., and Vary, C. P. H. (2006). Endoglin structure and function. J. Biol. Chem. 281, 25110-25123. 
Kulkarni, A. B., Huh, C. G., Becker, D., Geiser, A., Lyght, M., Flanders, K. C., Roberts, A. B., Sporn, M. B., Ward, J. M., and Karlsson, S. (1993). Transforming growth factor beta 1 null mutation in mice causes excessive inflammatory response and early death. Proc. Natl. Acad. Sci. U.S.A. 90, 770-774.

Kumar, I., Staton, C. A., Cross, S. S., Reed, M. W. R., and Brown, N. J. (2009). Angiogenesis, vascular endothelial growth factor and its receptors in human surgical wounds. Br. J. Surg. 96, 1484-1491.

Lancrin, C., Sroczynska, P., Stephenson, C., Allen, T., Kouskoff, V., and Lacaud, G. (2009). The haemangioblast generates haematopoietic cells through a haemogenic endothelium stage. Nature 457, 892-895.

Le, B. V., Franke, D., Svergun, D. I., Han, T., Hwang, H.-Y., and Kim, K. K. (2009). Structural and functional characterization of soluble endoglin receptor. Biochem. Biophys. Res. Commun. 383, 386-391.

Lebrin, F., Goumans, M.-J., Jonker, L., Carvalho, R. L. C., Valdimarsdottir, G., Thorikay, M., Mummery, C., Arthur, H. M., and Dijke, P. t. (2004). Endoglin promotes endothelial cell proliferation and TGF-[beta]/ALK1 signal transduction. $E M B O$ J. 23, 4018-4028.

Lechapt-Zalcman, E., PruliereEscabasse, V., Advenier, D., Galiacy, S., Charriere-Bertrand, C., Coste, A., Harf, A., d'Ortho, M. P., and Escudier, E. (2006). Transforming growth factor-betal increases airway wound repair via MMP-2 upregulation: a new pathway for epithelial wound repair? Am. J. Physiol. Lung Cell. Mol. Physiol. 290, L1277-L1282.

Lechler, T., and Fuchs, E. (2005). Asymmetric cell divisions promote stratification and differentiation of mammalian skin. Nature 437, 275-280.

Lee, N. Y., and Blobe, G. C. (2007). The Interaction of endoglin with $\beta$-arrestin2 regulates transforming growth factor- $\beta$-mediated erk activation and migration in endothelial cells. J. Biol. Chem. 282, 21507-21517.

Lee, N. Y., Ray, B., How, T., and Blobe, G. C. (2008). Endoglin promotes transforming growth factor betamediated Smad 1/5/8 signaling and inhibits endothelial cell migration through its association with GIPC. J. Biol. Chem. 283, 32527-32533.

Lee, P., Lee, D. J., Chan, C., Chen, S. W., Ch'en, I., and Jamora, C. (2009). Dynamic expression of epidermal caspase 8 simulates a wound healing response. Nature 458, 519-523.

Li, C., Issa, R., Kumar, P., Hampson, I. N., Lopez-Novoa, J. M., Bernabeu, C., and Kumar, S. (2003). CD105 prevents apoptosis in hypoxic endothelial cells. J. Cell Sci. 116, 2677-2685.

Li, F., Huang, Q., Chen, J., Peng, Y., Roop, D. R., Bedford, J. S., and Li, C. Y. (2010). Apoptotic cells activate the "phoenix rising" pathway to promote wound healing and tissue regeneration. Sci. Signal. 3, ra13.

Liu, M., and Horowitz, A. (2006). A PDZ-binding motif as a critical determinant of Rho guanine exchange factor function and cell phenotype. Mol. Biol. Cell 17, 1880-1887.

Liu, T., and Feng, X. H. (2010). Regulation of TGF-beta signalling by protein phosphatases. Biochem. J. 430, 191-198.

Llorca, O., Trujillo, A., Blanco, F. J., and Bernabeu, C. (2007). Structural model of human endoglin, a transmembrane receptor responsible for hereditary hemorrhagic telangiectasia. J. Mol. Biol. 365, 694-705.

Lonn, P., Moren, A., Raja, E., Dahl, M., and Moustakas, A. (2009). Regulating the stability of TGFbeta receptors and Smads. Cell Res. 19, 21-35.

Lutz, M., and Knaus, P. (2002). Integration of the TGF-beta pathway into the cellular signalling network. Cell. Signal. 14, 977-988.

Ma, J., Wang, Q., Fei, T., Han, J.-D. J., and Chen, Y.-G. (2007). MCP-1 mediates TGF- $\{$ beta $\}$-induced angiogenesis by stimulating vascular smooth muscle cell migration. Blood 109, 987-994.

Machado, M. J., and Mitchell, C. A. (2011). Temporal changes in microvessel leakiness during wound healing discriminated by in vivo fluorescence recovery after photobleaching. J. Physiol. (Lond.) 589, 4681-4696.

Mahmoud, M., Borthwick, G. M., Hislop, A. A., and Arthur, H. M. (2009). Endoglin and activin receptor-likekinase 1 are co-expressed in the distal vessels of the lung: implications for two familial vascular dysplasias, HHT and PAH. Lab. Invest. $89,15-25$.

Mani, S., Guo, W., Liao, M., Eaton, E., Ayyanan, A., Zhou, A., Brooks, M., Reinhard, F., Zhang, C., and Shipitsin, M. (2008). The epithelialmesenchymal transition generates cells with properties of stem cells. Cell 133, 704-715.

Mansilla, E., MarIn, G. H., Drago, H., Sturla, F., Salas, E., Gardiner, C., Bossi, S., Lamonega, R., Guzmán, A., Nuñez, A., Gil, M. A., Piccinelli, G., Ibar, R., and Soratti, C.
(2006). Bloodstream cells phenotypically identical to human mesenchymal bone marrow stem cells circulate in large amounts under the influence of acute large skin damage: new evidence for their use in regenerative medicine. Transplant. Proc. 38, 967-969.

Meurer, S. K., Tihaa, L., BorkhamKamphorst, E., and Weiskirchen, R. (2011). Expression and functional analysis of endoglin in isolated liver cells and its involvement in fibrogenic smad signalling. Cell. Signal. 23, 683-699.

Morasso, M. I., and Tomic-Canic, M. (2005). Epidermal stem cells: the cradle of epidermal determination, differentiation and wound healing. Biol. Cell 97, 173-183.

Moustakas, A., and Heldin, C. H. (2009). The regulation of TGFbeta signal transduction. Development 136 3699-3714.

Nath, R. K., LaRegina, M., Markham, H., Ksander, G. A., and Weeks, P. M. (1994). The expression of transforming growth factor type beta in fetal and adult rabbit skin wounds. J. Pediatr. Surg. 29, 416-421.

Nikiteas, N. I., Tzanakis, N., Theodoropoulos, G., Atsaves, V., Christoni, Z., Karakitsos, P., Lazaris, A. C., Papachristodoulou, A., Klonaris, C. and Gazouli, M. (2007). Vascular endothelial growth factor and endoglin (CD-105) in gastric cancer. Gastric Cancer 10, 12-17.

Okuda, K., Murata, M., Sugimoto, M. Saito, Y., Kabasawa, Y., Yoshie, H., Saku, T., and Hara, K. (1998). TGF-betal influences early gingival wound healing in rats: an immunohistochemical evaluation of stromal remodelling by extracellular matrix molecules and PCNA. J. Oral Pathol. Med. 27, 463-469.

Owens, P., Han, G., Li, A. G., and Wang, X. J. (2008). The role of Smads in skin development. J. Invest. Dermatol. 128, 783-790.

Oxmann, D., Held-Feindt, J., Stark, A. M., Hattermann, K., Yoneda, T., and Mentlein, R. (2008). Endoglin expression in metastatic breast cancer cells enhances their invasive phenotype. Oncogene 27 3567-3575.

Padgett, R. W., and Reiss, M. (2007). TGFbeta superfamily signaling: notes from the desert. Development 134, 3565-3569.

Pera, M. F., and Tam, P. P. (2010). Extrinsic regulation of pluripotent stem cells. Nature 465, 713-720.

Perlingeiro, R. C. R. (2007). Endoglin is required for hemangioblast and early hematopoietic development. Development 134, 3041-3048.
Pronk, C., Rossi, D., Mansson, R., Attema, J., Norddahl, G., Chan, C., Sigvardsson, M., Weissman, I., and Bryder, D. (2007). Elucidation of the phenotypic, functional, and molecular topography of a myeloerythroid progenitor cell hierarchy. Cell Stem Cell 1, 428-442.

Quesada, I. M., Del Bas, J. M., Blade, C., Ardevol, A., Blay, M., Salvado, M. J., Pujadas, G., Fernandez-Larrea, J., and Arola, L. (2007). Grape seed procyanidins inhibit the expression of metallothione in genes in human HepG2 cells. Genes Nutr. 2, 105-109.

Riekstina, U., Muceniece, R., Cakstina, I., Muiznieks, I., and Ancans, J. (2008). Characterization of human skin-derived mesenchymal stem cell proliferation rate in different growth conditions. Cytotechnology $58,153-162$.

Ross, S., and Hill, C. S. (2008). How the Smads regulate transcription. Int. J. Biochem. Cell Biol. 40, 383-408.

Ruscetti, F. W., Akel, S., and Bartelmez, S. H. (2005). Autocrine transforming growth factor-beta regulation of hematopoiesis: many outcomes that depend on the context. Oncogene 24 5751-5763.

Sánchez-Elsner, T., Botella, L. M., Velasco, B., Langa, C., and Bernabéu, C. (2002). Endoglin expression is regulated by transcriptional cooperation between the hypoxia and transforming growth factorbeta pathways. J. Biol. Chem. 277, 43799-43808.

Sandlund, J., Hedberg, Y., Bergh, A., Grankvist, K., Ljungberg, B., and Rasmuson, T. (2006). Endoglin (CD105) expression in human renal cell carcinoma. BJU Int. 97, 706-710.

Santibanez, J. F., Letamendia, A., PerezBarriocanal, F., Silvestri, C., Saura, M., Vary, C. P. H., Lopez-Novoa, J. M., Attisano, L., and Bernabeu, C. (2007). Endoglin increases eNOS expression by modulating Smad2 protein levels and Smad2-dependent TGF-beta signaling. J. Cell. Physiol. 210, 456-468.

Schmid, P., Cox, D., Bilbe, G., McMaster, G., Morrison, C., Stähelin, H. Lüscher, N., and Seiler, W. (1993). TGF-beta $s$ and TGF-beta type II receptor in human epidermis: differential expression in acute and chronic skin wounds. J. Pathol. 171 191-197.

Schultz, G. S. (2007). "The physiology of wound bed preparation," in Surgical Wound Healing and Management, eds M. S. Granick and R. L. Gamelli (London: Informa Healthcare, Inc.), 1-16. 
Semenza, G. L. (2007). "Regulation of angiogenesis and arteriogenesis by hypoxia-inducible factor-1," in Modern Concepts in Angiogenesis, eds M. Simons and G. M. Rubanyi (London: Imperial College Press), 175-216.

Shephard, P., Martin, G., Smola-Hess, S., Brunner, G., Krieg, T., and Smola, H. (2004). Myofibroblast differentiation is induced in keratinocytefibroblast co-cultures and is antagonistically regulated by endogenous transforming growth factor-\{beta and interleukin-1. Am. J. Pathol. 164, 2055-2066.

Shull, M. M., Ormsby, I., Kier, A. B., Pawlowski, S., Diebold, R. J., Yin, M., Allen, R., Sidman, C., Proetzel, G., Calvin, D., Annunziata, N., and Doetschman, T. (1992). Targeted disruption of the mouse transforming growth factorbeta 1 gene results in multifocal inflammatory disease. Nature 359, 693-699.

Smith, P. C., Cáceres, M., and Martinez, J. (2006). Induction of the myofibroblastic phenotype in human gingival fibroblasts by transforming growth factor-\&\#x03B2;1: role of RhoA-ROCK and c-Jun N-terminal kinase signaling pathways. J. Periodont. Res. 41, 418-425.

Tang, H., Low, B., Rutherford, S. A., and Hao, Q. (2005). Thrombin induces endocytosis of endoglin and type-II TGF-beta receptor and down-regulation of TGF-beta signaling in endothelial cells. Blood 105, 1977-1985.

Tao, S., and Sampath, K. (2010). Alternative splicing of SMADs in differentiation and tissue homeostasis. Dev. Growth Differ. 52, 335-342.

ten Dijke, P., Goumans, M.-J., and Pardali, E. (2008). Endoglin in angiogenesis and vascular diseases. Angiogenesis 11, 79-89.

Thiery, J. P., and Sleeman, J. P. (2006). Complex networks orchestrate epithelial-mesenchymal transitions. Nat. Rev. Mol. Cell Biol. 7, 131-142.

Thompson, H. G. R., Mih, J. D., Krasieva, T. B., Tromberg, B. J., and George, S. C. (2006). Epithelialderived TGF-beta2 modulates basal and wound-healing subepithelial matrix homeostasis. Am. J. Physiol.
Lung Cell. Mol. Physiol. 291, L1277L1285.

Tian, Y., Tang, S., and Luo, S. (2000). A study on the expressions and the correlation of TGF-beta and alphaSMA in scars. Zhonghua Zheng Xing Wai Ke Za Zhi 16, 75-77.

Torsney, E., Charlton, R., Parums, D., Collis, M., and Arthur, H. M. (2002). Inducible expression of human endoglin during inflammation and wound healing in vivo. Inflamm. Res. 51, 464-470.

Tredget, E. B., Demare, J., Chandran, G., Tredget, E. E., Yang, L., and Ghahary, A. (2005). Transforming growth factor-beta and its effect on reepithelialization of partial-thickness ear wounds in transgenic mice. Wound Repair Regen. 13, 61-67.

Turner, C. H., Chandran, A., and Pidaparti, R. M. (1995). The anisotropy of osteonal bone and its ultrastructural implications. Bone 17, 85-89.

Tyrone, J. W., Marcus, J. R., Bonomo, S. R., Mogford, J. E., Xia, Y., and Mustoe, T. A. (2000). Transforming growth factor $\{$ beta 3 promotes fascial wound healing in a new animal model. Arch. Surg. 135, 1154-1159.

Urbich, C., and Dimmeler, S. (2004). Endothelial progenitor cells: characterization and role in vascular biology. Circ. Res. 95, 343-353.

Valluru, M., Brown, N. J., Cross, S. S., Reed, M. W., and Staton, C. A. (2011). Blood vessel characterisation in human dermal wound repair and scarring. Br. J. Dermatol. 165, 221-224.

van Laake, L. W., van den Driesche, S., Post, S., Feijen, A., Jansen, M. A., Driessens, M. H., Mager, J. J., Snijder, R. J., Westermann, C. J. J., Doevendans, P. A., van Echteld, C. J., ten Dijke, P., Arthur, H. M., Goumans, M. J., Lebrin, F., and Mummery, C. L. (2006). Endoglin has a crucial role in blood cell-mediated vascular repair. Circulation 114, 2288-2297.

van Poll, D., Parekkadan, B., Borel Rinkes, I., Tilles, A., and Yarmush, M. (2008). Mesenchymal stem cell therapy for protection and repair of injured vital organs. Cell. Mol. Bioeng. 1, 42-50.

Vaughan, M. B., Howard, E. W., and Tomasek, J. J. (2000). Transforming growth factor-[beta] 1 promotes the morphological and functional differentiation of the myofibroblast. Exp. Cell Res. 257, 180-189.

Venkatesha, S., Toporsian, M., Lam, C. Hanai, J., Mammoto, T., Kim, Y. M., Bdolah, Y., Lim, K. H., Yuan, H. T., Libermann, T. A., Stillman, I. E., Roberts, D., D'Amore, P. A. Epstein, F. H., Sellke, F. W., Romero, R., Sukhatme, V. P., Letarte, M., and Karumanchi, S. A. (2006). Soluble endoglin contributes to the pathogenesis of preeclampsia. Nat. Med. 12, 642-649.

Wahl, S. M., Hunt, D. A., Wakefield, L. M., McCartney-Francis, N., Wahl, L. M., Roberts, A. B., and Sporn, M. B. (1987). Transforming growth factor type beta induces monocyte chemotaxis and growth factor production. Proc. Natl. Acad. Sci. U.S.A. 84, 5788-5792.

Wang, J., Jiao, H., Stewart, T. L. Shankowsky, H. A., Scott, P. G., and Tredget, E. E. (2007a). Increased TGF-\&\#x03B2;\&\#x2013;producing $\mathrm{CD} 4<\mathrm{b}\rangle+</ \mathrm{b}\rangle \mathrm{T}$ lymphocytes in postburn patients and their potential interaction with dermal fibroblasts in hypertrophic scarring. Wound Repair Regen. 15, 530-539.

Wang, J. F., Jiao, H., Stewart, T. L., Shankowsky, H. A., Scott, P. G. and Tredget, E. E. (2007b). Fibrocytes from burn patients regulate the activities of fibroblasts. Wound Repair Regen. 15, 113-121.

Watabe, T., and Miyazono, K. (2009). Roles of TGF-beta family signaling in stem cell renewal and differentiation. Cell Res. 19, 103-115.

Werner, S., Krieg, T., and Smola, H. (2007). Keratinocyte-fibroblast interactions in wound healing. $J$. Invest. Dermatol. 127, 998-1008.

Wrighton, K. H., Lin, X., and Feng, X. H. (2009). Phospho-control of TGFbeta superfamily signaling. Cell Res. 19, 8-20.

Wu, J., Basha, M. R., and Zawia, N. H. (2008). The environment, epigenetics and amyloidogenesis. J. Mol. Neurosci. 34, 1-7.

Xie, L., Law, B. K., Chytil, A. M., Brown, K. A., Aakre, M. E., and Moses, H. L. (2004). Activation of the Erk pathway is required for TGF- $\beta 1$ induced EMT in vitro. Neoplasia 6, 603-610.

Xiong, J.-W. (2008). Molecular and developmental biology of the hemangioblast. Dev. Dyn. 237, 1218-1231.

Yuji, Y., Vincent, H., Satoshi, I., Kunihiko, Y., and Ichiro, K. (2005) Mesenchymal-epithelial interactions in the skin: aiming for site-specific tissue regeneration. J. Dermatol. Sci. 40, 1-9.

Zhang, Y. E. (2009). Non-Smad pathways in TGF-beta signaling. Cell Res. 19, 128-139.

Zhu, X.-Y., Fang, C.-H., Zhang, L.-Y., Zuo, D.-M., and Chen, Z.-L. (2005). Expressions and role of endogenetic matrix metalloproteinases-9 and transforming growth factorbeta during wound healing of blast injury. Di Yi Jun Yi Da Xue Xue 25, 844-846.

Zhu, Y., Sun, Y., Xie, L., Jin, K., Sheibani, N., and Greenberg, D. A. (2003) Hypoxic induction of endoglin via mitogen-activated protein kinases in mouse brain microvascular endothelial cells. Stroke 34, 2483-2488.

Zvaifler, N. J., Marinova-Mutafchieva, L., Adams, G., Edwards, C. J., Moss, J., Burger, J. A., and Maini, R. N. (2000). Mesenchymal precursor cells in the blood of normal individuals. Arthritis Res. 2, 477-488.

Conflict of Interest Statement: The authors declare that the research was conducted in the absence of any commercial or financial relationships that could be construed as a potential conflict of interest.

Received: 07 September 2011; accepted: 10 November 2011; published online: 29 November 2011.

Citation: Valluru $M$, Staton CA, Reed MWR and Brown NJ (2011) Transforming growth factor- $\beta$ and endoglin signaling orchestrate wound healing. Front. Physio. 2:89. doi: 10.3389/fphys.2011.00089

This article was submitted to Frontiers in Vascular Physiology, a specialty of Frontiers in Physiology.

Copyright (C) 2011 Valluru, Staton, Reed and Brown. This is an open-access article distributed under the terms of the Creative Commons Attribution Non Commercial License, which permits noncommercial use, distribution, and reproduction in other forums, provided the original authors and source are credited. 